\title{
PACIENTŲ POŽIŪRIS İ TELEMEDICINOS PASLAUGŲ TEIKIMĄ NAMUOSE
}

\author{
Ernesta Remeikaitė \\ Mykolo Romerio universiteto Politikos ir vadybos fakulteto \\ Politikos mokslų institutas \\ Valakupių g. 5, LT-10101 Vilnius, Lietuva \\ Elektroninis paštas ernestarrr@gmail.com \\ Gintarè Petronytè \\ Mykolo Romerio universiteto Politikos ir vadybos fakulteto \\ Politikos mokslų institutas \\ Valakupių g. 5, LT-10101 Vilnius, Lietuva \\ Elektroninis paštas ginpetr@mruni.eu
}

Pateikta 2014 m. rugsejjo 2 d., parengta spausdinti 2014 m. spalio 3 d.

doi:10.13165/SPV-14-2-7-03

\section{Santrauka}

Šiame straipsnyje analizuojamas telemedicinos paslaugu diegimas sveikatos sektoriuje. Tyrimo tikslas - įvertinti pacientu požiūrị i sveikatos priežiūros paslaugu teikima namuose, taikant telemedicinos priemones. $2013 \mathrm{~m}$. rugséjo-lapkričio men. atliktame tyrime taikant anketines aplausos metoda dalyvavo $27940-76 \mathrm{~m}$. amžiaus Vilniaus Šeškiness poliklinikos pacientai. Tyrimo duomenimis, pacientai nèra pakankamai informuoti apie elektronines sveikatos, taip pat ir telemedicinos, sprendimu igyvendinima sveikatos sektoriuje. Nors pacientai bütu linkę naudotis sveikatos priežiūros paslaugomis namuose, taikant telemedicinos priemones, tačiau jiems nelabai priimtinas netiesioginis bendravimas su gydytoju, dèl ko rečiau naudotusi ligu diagnozavimo, gydymo ir sveikatos stebessenos paslaugomis. Be to, pacientams kyla nuogąstavimų dèl teigiamu sveikatos priežiūros paslaugü prieinamumo ir ju kokybes pokyčiu, sveikatos informacijos saugumo, gydytojų klaidu, telemedicinos priemoniu nepatogumo ir nemokejimo jomis naudotis bei asmeninių lèšu investavimo i jų isigijimą.

Reikšminiai žodžiai: telemedicina, telemedicinos paslaugos namuose, naudojimosi telemedicinos paslaugomis kliūtys, pacientai. 


\section{İvadas}

Inovatyvių technologijų vystymasis suteikia naujas sveikatos priežiūros galimybes, tačiau jų diegimas daugelyje šalių išlieka iššūkiu. Pasaulio sveikatos organizacija, Ekonominio bendradarbiavimo ir plètros organizacija, Europos Sąjungos ir kitos institucijos atsižvelgdamos ił nuotolinių sveikatos priežiūros paslaugų teikimo svarbą valstybių viduje ir tarp valstybių, remia bendradarbiavimą, sprendimus ir veiksmus šioje srityje ${ }^{1}$. Europos Komisijos tikslinès politinès iniciatyvos ir elektroninès sveikatos politikos igyvendinimo veiksmai paskatino telemedicinos paslaugų ir jų teikimo plètrą, ${ }^{2,3}$. Telemedicina apima telekomunikacinių priemonių bei informacinių technologijų naudojimą, teikiant ligų prevencijos, diagnostikos, gydymo paslaugas ir atliekant tolesnę paciento stebėseną ${ }^{4}$. Jos taikymas prisideda prie sveikatos priežiūros sistemų problemų sprendimo ir jų tvarumo išlaikymo ateityje ${ }^{5}$.

Nepaisant telemedicinos teikiamų galimybių, ji dar nèra plačiai taikoma daugelio šalių sveikatos sektoriuose $e^{6}$. Lietuvoje padètas pagrindas telemedicinos paslaugu plètrai: patvirtinta Nacionalinè elektroninès sveikatos 2007$2015 \mathrm{~m}$. strategija ${ }^{7}$ ir Lietuvos elektroninès sveikatos sistemos 2012-2020 m. strategijos vizijos metmenys ${ }^{8}$, kuriuose demesys skiriamas telemedicinos priemoniu diegimui sveikatos sektoriuje, parengtas teisès aktas, reglamentuojantis teleme-

1 Communication from the Commission to the European Parliament, the Council, the European Economic and Social Committee and the Committee of the Regions on eHealth Action Plan 20122020 - Innovative healthcare for the $21^{\text {st }}$ century. COM/2012/0736.

2 Ibid.

3 Commission staff working document on the applicability of the existing EU legal framework to telemedicine services accompanying the document Communication from the Commission to the European Parliament, the Council, the European Economic and Social Committee and the Committee of the Regions on eHealth Action Plan 2012-2020 - Innovative healthcare for the $21^{\text {st }}$ century. SWD/ 2012/0414.

4 Communication from the Commission to the European Parliament, the Council, the European Economic and Social Committee and the Committee of the Regions of 4 November 2008 on telemedicine for the benefit of patients, healthcare systems and society.COM/2008/0689.

5 Supra note 1.

${ }_{6}$ World Health Organization. Telemedicine: opportunities and developments in member states: report on the second global survey on eHealth. WHO: Geneva, 2010, p. 94.

7 Lietuvos Respublikos sveikatos apsaugos ministro 2007 m. spalio 9 d. ịsakymas Nr. V-811 „Dèl Lietuvos e. sveikatos 2007-2015 m. plètros strategijos patvirtinimo“. Valstybès žinios. 2007, Nr. 108-4430.

8 Dučinskas, N. Lietuvos e. sveikatos sistemos 2012-2020 metų strategijos vizijos metmenys. Lietuvos Respublikos sveikatos apsaugos ministerija [interaktyvus]. Vilnius, 2012 [žiūrèta 2014-06-29]. <http://www.pylimas.lt/documents/1\%20E.\%20sveikatos\%20strategijos\%20metmenys\%20201201-25\%20\%5BCompatibility\%20Mode\%5D.pdf>. 
dicinos paslaugų teikimą ${ }^{9}$, be to, atlikti keli moksliniai tyrimai ${ }^{10,11,12}$, sveikatos priežiūros ístaigose vykdomi projektai ${ }^{13,14}$ telemedicinos srityje. Kitose šalyse atlikta nemažai mokslinių tyrimų, kuriuose analizuojamas telemedicinos priemonių naudojimas įvairiose sveikatos priežiūros srityse - kardiologijoje $e^{15}$, dermatologijoje ${ }^{16}$, onkologijoje $\mathrm{e}^{17}$, psichiatrijoje $\mathrm{e}^{18}$, be to, vertinamas telemedicinos paslaugų ekonominis ir klinikinis efektyvumas ${ }^{19,20}$, telemedicinos paslaugų taikymas namuose ${ }^{21}$ bei pacientu pasitenkinimas telemedicinos paslaugomis ${ }^{22,23}$. Dèl visuomenès senėjimo didejjant sveikatos sektoriaus išlaidoms telemedicinos priemonių taikymas namuose vyresnio amžiaus pacientų sveikatos priežiūroje tampa vis aktualesnis, siekiant užtikrinti sveikatos priežiūros paslaugų prieina-

9 Lietuvos Respublikos sveikatos apsaugos ministro 2014 m. sausio 27 d. ịsakymas Nr. V-116 „Dèl telemedicinos paslaugų teikimo tvarkos aprašo patvirtinimo“. Teisès aktų registras [žiūrèta 201408-10]. <https://www.e-tar.lt/portal/legalAct.html?documentId=4261443088ac11e397b5c02d319 $7 \mathrm{f} 382>$.

10 Punys, J.; Punys, V.; Eichelberg, M., et al. Pilotinis SAMTA projektas: nebrangios telemedicininès paslaugos periferiniams rajonams. Medicinos informatika: tarptautinès konferencijos pranešimų medžiaga, 2001 m. rugsèjo mèn. 13-14 d. Kaunas: Technologija, 2002, p. 19-32.

11 Vaičiūnaitè, L. Ligonių, sergančiu išemine širdies liga, pasitenkinimas ir paklusnumas naudojantis telemedicinos paslaugomis. Magistro darbas. Kaunas: Kauno medicinos universitetas, 2007.

12 Rugieniūte, A. Telemedicinos panaudojimo galimybiu ìvertinimas Kauno medicinos universiteto kliniku padaliniu vadovu požiūriu. Magistro darbas. Kaunas: Kauno medicinos universitetas, 2008.

13 Lietuvos sveikatos mokslų universiteto ligoninè viešoji įstaiga Kauno klinikos. Telemedicinos taikymas Vakaru Lietuvos kardiologijai [žiūrèta 2014-10-05]. <http://www.esparama.lt/ paraiska?id=33365\&pgsz $=10>$.

14 Viešoji ịstaiga Vilniaus universiteto ligoninès Santariškių klinikos. Pažangios telemedicinos paslaugos [žiūrèta 2014-10-05]. <http://www.esparama.lt/paraiska?id=31987\&pgsz=10>.

15 Brownsell, S. Supporting long term conditions and disease management through telecare and telehealth: evidence and challenges [interaktyvus]. London:CSIP, 2008 [žiūrèta 2014-06-25]. $<$ http://www.dhcarenetworks.org.uk/_library/Resources/Telecare/Support_materials/BriefingTelehealth_SB_Final2.doc>.

16 Browns, I. R.; Collins, K.; Walters, S. J., et al. Telemedicine in dermatology: a randomized controlled trial. Health Technology Assessment. 2006, 10 (43):1-39.

17 Nimako, K.; Kiong, Lu S.; Ayite, B., et al. A pilot study of a novel home telemonitoring system for oncology patients receiving chemotherapy. Journal of Telemedicine and Telecare. 2013, 19 (3): $148-152$.

18 Hyler, S. E.; Gangure, D. P.; Batchelder, S. T. Can telepsychiatry replace in-person psychiatric assessments? A review and meta-analysis of comparison studies. CNS Spectrums. 2005, 10(5): 403-413.

19 Whitten, P. S.; Mair, F. .S.; Haycox A., et al. A systematic review of cost effectiveness studies of telemedicine interventions. BMJ. 2002, 324: 1434.

20 Currell, R.; Urquhart, C.; Wainwright, P., et al. Telemedicine versus face to face patient care: effects on professional practice and health care outcomes. Cochrane Database of Systematic Reviews. 2000, 2: CD002098.

${ }^{21}$ Dellifraine, J. L.; Dansky, K. H. Home-based Telehealth: a Review and Meta-analysis. Journal of Telemedicine and Telecare. 2008, 14(2): 62-66.

22 Mair, F.; Whitten, P. Systematic review of studies of patient satisfaction with telemedicine. $B M J$. 2000, 320(7248):1517-1520.

23 Currell, R.; Urquhart, C.; Wainwright, P., et al., op. cit. 
mumą ir jų kokybę. Lietuvoje diegiant inovatyvius sveikatos priežiūros paslaugu teikimo būdus, sveikatos politikos formuotojams ir igyvendintojams trūksta informacijos, kuri paremtų tolesnius jų sprendimus telemedicinos plètros srityje. Šio tyrimo tikslas - ịvertinti pacientų požiūrị ị sveikatos priežiūros paslaugų teikimą namuose, taikant telemedicinos priemones.

\section{Tyrimo medžiaga ir metodai}

Remiantis Vilniaus Šeškinès poliklinikos 2013 m. pateikta informacija apie pacientų amžių, apskaičiuota reprezentatyvi imtis (patikimumo lygmuo 95 proc., pasikliautinasis intervalas \pm 6 proc.). Tyrime dalyvavo $27940-76 \mathrm{~m}$. (amžiaus vidurkis $53 \mathrm{~m}$.) pacientai: 171 (61,3 proc.) moteris ir 105 (37,6 proc.) vyrai. 46 proc. tyrime dalyvavusių pacientų turejjo aukštąji universitetinị išsilavinimą, 21,9 proc. - aukštesnijji, 32,1 proc. - vidurinị ar žemesnị išsilavinimą. Pagal pajamas skaičiuojant vienam šeimos asmeniui per mėnesį, 37,5 proc. pacientų nurodè, kad jos buvo iki 800 litų, atitinkamai 41,3 proc. - nuo 801 iki 1400 litų, 21,2 proc. - daugiau nei 1401 litas.

Tyrimas atliktas $2013 \mathrm{~m}$. rugsèjo-lapkričio mèn., taikant autorių parengtą ir žvalgomojo tyrimo metu išbandytą klausimyną. Sveikatos priežiūros paslaugu teikimas namuose, taikant telemedicinos priemones pacientų požiūriu vertintas šiose srityse: pacientų informuotumas apie elektroninès sveikatos sprendimų diegimą sveikatos sektoriuje ir jo informavimo šaltiniai, pacientų nuomoné apie telemedicinos priemonių naudojimą ir ją formuojantys veiksniai, kliūtys kylančios teikiant sveikatos priežiūros paslaugas namuose, taikant telemedicinos priemones.

Duomenų analizei naudotas SPSS for Windows statistinis paketas (20 versija). Taikyta aprašomoji statistika: atvejų dažniai (procentai). Statistiniai požymių ryšiai vertinti taikant chi kvadrato $(\chi 2)$ kriterijų. Pasirinktas statistinio reikšmingumo lygmuo $\mathrm{p}<0,05$.

\section{Tyrimo rezultatai}

\section{Informuotumas apie elektroninès sveikatos sprendimų diegimą sveikatos sektoriuje}

Tyrimo duomenimis, 41,6 proc. pacientų teigè žinantys apie šalyje ịgyvendinamą elektroninès sveikatos strategiją, o 58,4 proc. nežinojo apie ją. Pusè $(50,2$ proc.) pacientų nurodè esantys nepakankamai informuoti apie informacinių technologijų naudojimo galimybes sveikatos priežiūros įstaigose, penktadalis $(19,4$ proc.) teigè pakankamai informuoti apie jas, o trečdalis $(30,5$ proc.) negalèjo įvertinti savo informuotumo lygio. 
Vertinant pacientų informuotumą apie sveikatos priežiūros paslaugų teikimą namuose, taikant telemedicinos priemones, nustatyta, kad 58,8 proc. pacientų nežinojo apie tokị paslaugų teikimo būdą, o 41,2 proc. teigè žinantys apie jị. Pacientai, žinantys apie telemedicinos priemonių taikymą sveikatos priežiūroje, pagrindiniais jų informavimo šaltiniais įvardijo žiniasklaidą ( 21,17 proc.) ir sveikatos priežiūros specialistus (20,72 proc.), rečiau jie nurodè internetą $(17,57$ proc.), spaudą (15,77 proc.) ir šeimą, draugus, pažįstamus (13,51 proc.).

\section{Požiūris ị sveikatos priežiūros paslaugų teikimą namuose, taikant telemedicinos priemones}

Apie trečdalis (30,5 proc.) pacientų turèjo teigiamą nuomonę apie sveikatos priežiūros paslaugų teikimą namuose, taikant telemedicinos priemones, apie dešimtadalis $(12,4$ proc.) - neigiamą, trečdalis (27,6 proc.) - neutralią nuomonę, dar trečdalis (29,5 proc.) pacientų neturejjo nuomonès. Vertinant pacientų nuomonę apie šio paslaugų teikimo būdo reikalingumą, apie trečdalis ( 37,3 proc.) nurodè, kad sveikatos priežiūros paslaugų teikimas namuose, taikant telemedicinos priemones, yra reikalingas, 22,1 proc. - nei reikalingas, nei nereikalingas, 17,4 proc. - kad nereikalingas. Apie ketvirtadalis (23,2 proc.) pacientų neturèjo nuomonès šiuo klausimu.

Tyrimo duomenimis, 44,2 proc. pacientų sutiktų naudotis sveikatos priežiūros paslaugomis namuose, taikant telemedicinos priemones, 28,4 proc. - nesutiktų, o apie trečdalis (27,3 proc.) pacientų nuomonès neturëjo. Tyrime buvo siekiama nustatyti pacientų požiūrị ị sveikatos priežiūros paslaugas, teikiamas taikant telemedicinos priemones, kuriomis jie naudotųsi namuose. Pacientai linkę naudotis ligų prevencijos (72,3 proc.), elektroninio recepto išrašymo (70,8 proc.), individualios konsultacijos telefonu (67,9 proc.), sveikatos duomenų prieigos (65,1 proc.), sveikatinimo informacijos suteikimo (58,8 proc.), skubiosios pagalbos (57,2 proc.) bei nuotolinių mokymų ( 51,0 proc.) paslaugomis (1 pav.) Tuo tarpu pacientai rečiau pritarė diagnostikos (18,9 proc.), gydymo (26,1 proc.), sveikatos būklès stebėsenos (24,0 proc.), slaugos ( 21,1 proc.) bei skubios pagalbos (20,3 proc.) paslaugų teikimui namuose, taikant telemedicinos priemones.

Analizuojant veiksnius, turinčius įtakos apsisprendimui naudotis telemedicinos priemonèmis namuose, nustatyta, kad 38,7 proc. pacientų pirmenybę teiktų galimybei patiems praktiškai išbandyti priemones, o 28 proc. norètų sužinoti kitų pacientų, kuriems buvo teiktos sveikatos priežiūros paslaugos, taikant telemedicinos priemones, atsiliepimus. 25,3 proc. pacientų pažymėjo, kad jų apsisprendimui naudoti telemedicinos priemones turètų informacijos apie telemediciną sklaida. 


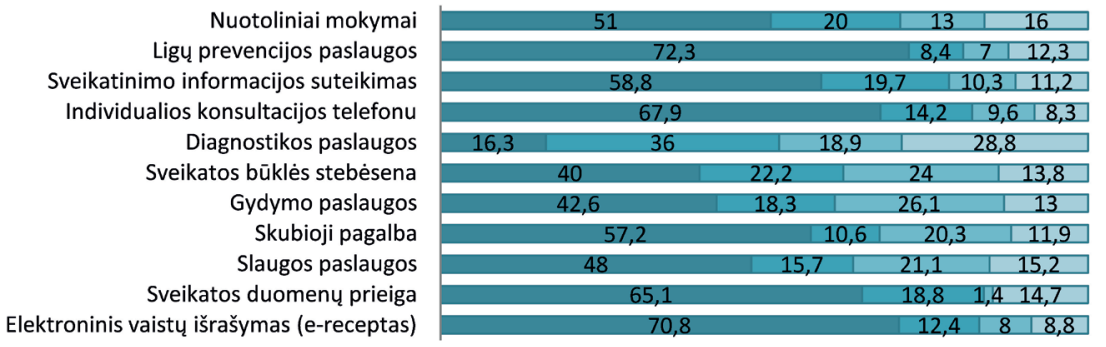

$\begin{array}{lllllllllll}0 \% & 10 \% & 20 \% & 30 \% & 40 \% & 50 \% & 60 \% & 70 \% & 80 \% & 90 \% & 100 \%\end{array}$

$\square$ Visiškai sutinka ir sutinka $\square$ Nei sutinka, nei nesutinka

$\square$ Nesutinka ir visiškai nesutinka $\square$ Neturi nuomonès

1 pav. Pacientų požiūris ị sveikatos priežiūros paslaugas, kuriomis naudotųsi namuose, taikant telemedicinos priemones, proc.

Tyrime vertintas pacientų požiūris ị telemedicinos priemonių taikymo poveikị teikiamų sveikatos priežiūros paslaugų prieinamumui ir jų kokybei. 17,9 proc. pacientų teigé, kad telemedicinos priemonių taikymas pagerins sveikatos priežiūros paslaugų kokybę, o 47,2 proc. -prieinamumą. Apie pusė pacientų nurodè, kad sveikatos priežiūros paslaugų kokybè ir prieinamumas, taikant telemedicinos priemone, nepasikeis (2 pav.).

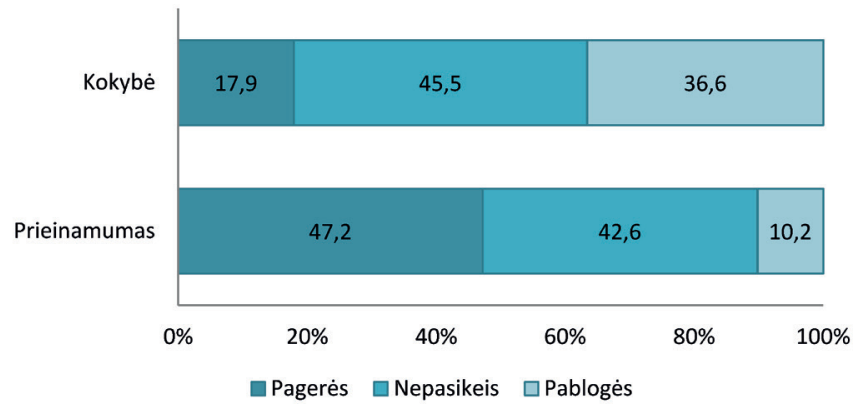

2 pav. Pacientų požiūris ị sveikatos priežiūros paslaugų prieinamumą ir kokybę, taikant telemedicinos priemones, proc.

\section{Sveikatos priežiūros paslaugų teikimo namuose, taikant telemedicinos priemones, kliūtys}

Tyrime analizuotas pacientų požiūris ị jų dalyvavimą diegiant elektroninès sveikatos sprendimus sveikatos priežiūros įstaigose. 40,1 proc. pacientų linkę 
manyti, kad neatsižvelgiama ị jų nuomonę sveikatos priežiūros paslaugų teikimo klausimais, 20,2 proc. - kad atsižvelgiama, likę (39,7 proc.) neturèjo nuomonès.

Atsižvelgiant, kad informacinès technologijos laikomos svarbia telemedicinos priemonių naudojimo dalimi, vertintas pacientų kompiuterinis raštingumas. 43,9 proc. pacientų nurode turintys labai gerus ar gerus kompiuterinio raštingumo ịgūdžius, 29,5 proc. - patenkinamus, 23,7 proc. - labai blogus ir blogus, o likę (2,9 proc.) neturèjo nuomonès.

Tyrime buvo siekiama išsiaiškinti, ar pacientai linkę investuoti asmenines lèšas reikalingoms telemedicinos priemonèms įsigyti. 40,3 proc. pacientų nesutiktų savo lëšomis įsigyti telemedicinos priemonių, 32 proc. - sutiktų, o 23,4 proc. nurodè neturintys nuomonès. Analizuojant galimas kliūtis nustatyta, kad trečdaliui (34 proc.) pacientų nekiltų jokių nepatogumų naudojantis telemedicinos priemonèmis, tačiau apie pusè ( 45,5 proc.) nurodé, kad jiems kiltų kokių nors nepatogumų. Apie penktadalis (20,52 proc.) pacientų nuomonès šiuo klausimu neturèjo.

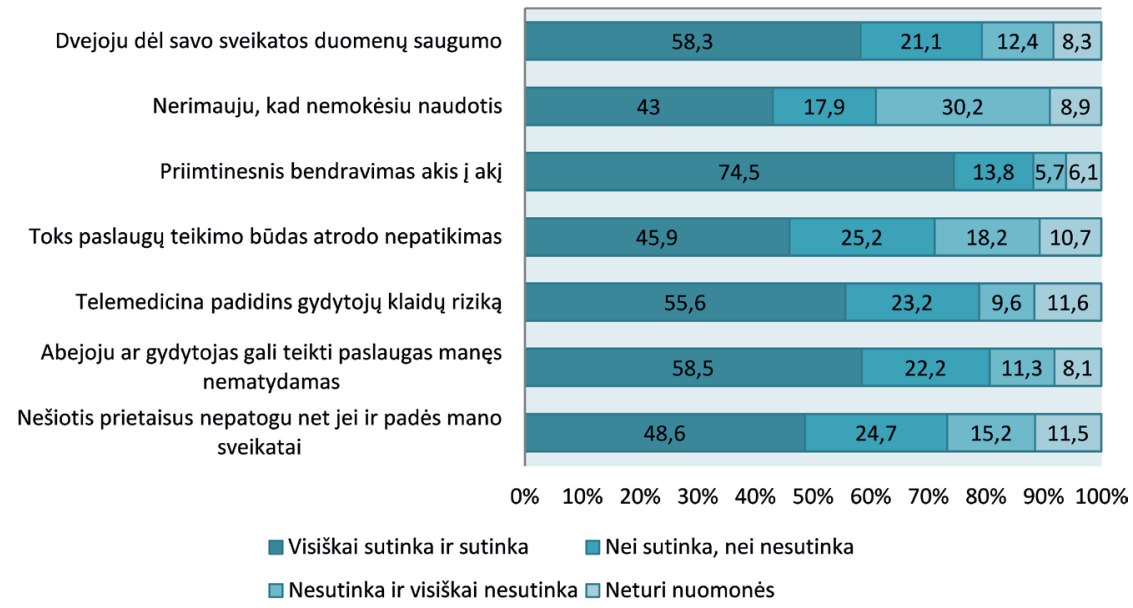

3 pav. Kliūtys ribojančios pacientų naudojimąsi sveikatos priežiūros paslaugomis, taikant telemedicinos priemones, proc.

Tyrime buvo nustatytos pagrindinès kliūtys, ribojančios naudojimąsi sveikatos priežiūros paslaugomis, taikant telemedicinos priemones. Dviem trečdaliams (74,5 proc.) pacientu priimtinesnis tiesioginis bendravimas su gydytoju. 58,5 proc. pacientų abejonių kèlè sveikatos priežiūros paslaugų teikimas gydytojui nematant paciento, o 58,3 proc. abejojo dèl sveikatos duomenų saugumo (3 pav.). Daugiau nei pusè (55,6 proc.) pacientų nurodè, kad telemedicinos priemonių taikymas padidins gydytojų klaidų riziką, be to, 45,9 proc. pacientų toki sveikatos priežiūros paslaugų teikimo būdą įvardijo nepatikimu. 48,6 proc. teigè, 
kad nešiotis telemedicinos priemones gali būti nepatogu, o 43 proc. abejojo, kad nemokès naudotis telemedicinos priemonèmis.

\section{Rezultatų aptarimas}

Lietuvoje, kaip ir kitose šalyse, sveikatos sektoriuje igyvendinami elektroninès sveikatos sprendimai ir diegiamos naujos paslaugos, paremtos moderniomis informacinèmis technologijomis. Telemedicina tampa viena iš inovatyvių sveikatos priežiūros paslaugų teikimo būdų, prisidedančių prie sveikatos sistemų efektyvumo, be to, ji laikoma sveikatos priežiūros netolygumų mažinimo ir sveikatos priežiūros paslaugų prieinamumo gerinimo priemone ${ }^{24,25}$. Skirtingose šalyse igyvendinami pilotiniai projektai, atliekami tyrimai ir sveikatos technologijų vertinimai, paremiantys politinius ir praktinius telemedicinos diegimo sprendimus.

Lietuvos strateginiuose dokumentuose i̇vardintas telemedicinos priemonių diegimas sveikatos sektoriuje ${ }^{26,27}$, o iggyvendinant šių dokumentų nuostatas nuo $2014 \mathrm{~m}$. gegužès $1 \mathrm{~d}$. šalyje pradètos teikti telemedicinos paslaugos, įtraukiant aukštos kvalifikacijos sveikatos priežiūros specialistų nuotolines konsultacijas $^{28}$. Šis naujas sveikatos priežiūros paslaugų teikimas reikalauja techninių, organizacinių ir teisinių klausimų sprendimo, siekiant užtikrinti tinkamas paslaugų teikimo sąlygas, taip pat pokyčių sveikatos priežiūros sistemoje.

Atliktas vienas pirmųjų tyrimų, analizuojančių telemedicinos paslaugų teikimą namuose, savalaikis ir aktualus praktine prasme, nes diegiamos telemedicinos priemonès, teikiant sveikatos priežiūros paslaugas, o jų pritaikymo nauda ir poveikis priklauso nuo priimtinumo pacientams. Tyrimo duomenimis, pacientai linkę naudotis sveikatos priežiūros paslaugomis namuose, taikant telemedicinos priemones, tačiau jiems mažai priimtinos ligų diagnozavimo, gydymo ir sveikatos stebėsenos paslaugos. Be to, pacientams kyla nuogąstavimų dẻl teigiamų sveikatos priežiūros paslaugų prieinamumo ir jų kokybès pokyčių, taikant telemedicinos priemones. Tokius tyrimo rezultatus galima paaiškinti pacientų nepakankamu informuotumu apie elektroninès sveikatos, taip pat telemedicinos, sprendimų diegimą ir igyvendinimą sveikatos sektoriuje, jų menku įtraukimu ị sveikatos priežiūros paslaugų teikimo modernizavimo procesus. Nors pacientai pripažistami vienais pagrindinių sveikatos sistemos dalyvių, tačiau atliktas tyrimas leidžia teigti, kad i jų teises išreikšti nuomonę bei dalyvauti priimant sprendimus dèl jų sveikatos priežiūros mažai atsižvelgiama. Šalių sveikatos politikoje atspirties tašku laikomos piliečių ir pacientų teisès, apimančios dalyvavimą ir

\footnotetext{
24 Supra note 7.

25 Supra note 1.

26 Supra note 7.

27 Dučinskas, N., supra note 8.

28 Supra note 9.
} 
įtaką priimant sprendimus, įskaitant jų sveikatos raštingumą ${ }^{29}$. Atliktas tyrimas išryškino sveikatos politikos igyvendinimo probleminę sritį: inovacijos pacientų sveikatos priežiūroje diegiamos, tačiau patys pacientai mažai informuoti apie jas. Visuomenès informavimo apie diegiamas naujas sveikatos priežiūros paslaugas ir komunikacijos strategijos sukūrimas bei jos igyvendinimas tampa pagrindine šių paslaugų naudojimosi prielaida.

Tyrimo duomenys leidžia prognozuoti, kad Lietuvos elektroninès sveikatos strategijoje numatytos nuotolinès pagyvenusių bei lètinėmis ligomis sergančių pacientų stebėsenos diegimas gali būti nepriimtinas pacientams, nepaisant įrodymais pagrịstų sprendimų sveikatos priežiūroje ir diegiamų inovacijų lètinių ligų valdyme. Remiantis Kanados vaistų ir sveikatos technologijų vertinimo agentūros atliktu vertinimu, pacientų sveikatos būklès stebėsena ir konsultacijos telefonu namuose laikoma efektyvia intervencija valdant kai kurias lètines ligas ${ }^{30}$. Šių priemonių taikymas pagerino sergančiųjų cukriniu diabetu gliukozès kontrolę, sumažino pacientų mirtingumą nuo širdies nepakankamumo, be to, pacientai rečiau naudojosi sveikatos priežiūros paslaugomis ${ }^{31}$. Tačiau trūksta įrodymų apie telemedicinos priemonių taikymo ekonominị efektyvumą ${ }^{32,33,34}$.

Atliktas tyrimas leidžia teigti, kad daugelis naudojimosi sveikatos priežiūros paslaugomis, taikant telemedicinos priemones, kliūčių kyla dèl pacientų nepakankamo pasitikejimo nauju sveikatos priežiūros paslaugų teikimo būdu ir informacijos apie ji trūkumo. Pažymètina, kad telemedicinos priemonių taikymo namuose kliūtys tarpusavyje susijusios, todèl dalyvaujantiems sveikatos priežiūros paslaugų planavimo ir jų diegimo procesuose svarbu iš anksto numatyti veiksmingas priemones, šalinančias kliūtis. Kitose šalyse atlikti tyrimai vienareikšmiškai rodo, kad pacientai patenkinti telemedicinos paslaugomis namuo$\mathrm{se}^{35,36}$. Pažymètina, kad dalis nuotolinès sveikatos priežiūros intervencijų lieka neịvertintos ir neįdiegtos praktikoje, nes pacientai atsisako dalyvauti tyrimuose dèl taikomų priemonių nepatogumo, nemokèjimo jomis naudotis, pirmenybès teikimo ịprastam sveikatos priežiūros paslaugų teikimui ir kitų priežasčių ${ }^{37}$.

29 Commission White Paper of 23 October 2007 Together for health: A strategic approach for the EU 2008-2013. COM/2007/ 630.

30 Tran, K.; Polisena, J.; Coyle, D., et al. Home telehealth for chronic disease management. International Journal of Technology Assessment in Healthcare. 2008, 25(3): 339-349.

$31 \quad$ Ibid., p. 339-349.

32 Ibid.

33 Currell, R; Urquhart, C.; Wainwright, P., et al., supra note 20.

34 Whitten, P. S.; Mair, F. S.; Haycox A., et al., supra note 19.

35 Mair, F.; Whitten, P., supra note 22, p. 1517-1520.

36 Chae, Y. M.; Lee, J. H.; Ho, S. H., et al. Patient satisfaction with telemedicine in home health services for the elderly. International Journal of Medical Informatics. 2001, 61(2-3): 167-173.

37 Sanders, C.; Rogers, A.; Bowen, R., et al. Exploring barriers to participation and adoption of telehealth and telecare within the whole system demonstrator trial: a qualitative Study. $B M C$ Health Services Research. 2012, 12: 220. 


\section{Išvados}

1. Apie trečdalis (30,5 proc.) pacientų turèjo teigiamą nuomonę apie sveikatos priežiūros paslaugų teikimą namuose, taikant telemedicinos priemones, apie dešimtadalis (12,4 proc.) - neigiamą, likę (27,6 proc.) - neutralią nuomonę. Tyrimo duomenimis, 44,2 proc. pacientų sutiktų naudotis telemedicinos priemonemis namuose, 28,4 proc. - nesutiktų, o 27,3 proc. - neturejo nuomonès. Pacientai linkę rečiau naudotis ligų diagnozavimo, gydymo ir sveikatos stebèsenos paslaugomis namuose, taikant telemedicinos priemones, tuo tarpu dažniau - ligų prevencijos, elektroninio vaistų recepto išrašymo ir konsultavimo telefonu paslaugomis. Apie pusé pacientų teigè, kad telemedicinos priemonių taikymas nepakeis sveikatos priežiūros paslaugų kokybės (45,5 proc.) ir jų prieinamumo (42,6 proc.).

2. Nustatytos pagrindinès sveikatos priežiūros paslaugų teikimo namuose, taikant telemedicinos priemones, kliūtys: pacientų noras tiesiogiai bendrauti su gydytoju, jų nuogąstavimai dèl informacijos saugumo, gydytojų klaidų, telemedicinos priemonių nepatogumo ir nemokèjimo jomis naudotis bei asmeninių lèšų investavimo ị jų ịsigijimą.

\section{Pasiūlymai}

Sveikatos priežiūros įstaigoms sudaryti galimybes pacientams įsitraukti $\mathfrak{i}$ sprendimų priemimo procesus, vykdant jų apklausas, organizuojant susitikimus su pacientų organizacijomis.

Telemedicinos paslaugų diegimą namuose organizuoti nuo mažiau individualizuotų paslaugų, pavyzdžiui, nuotoliniai mokymai, informavimas apie ligų prevencijos paslaugas, elektroninio recepto ar elektroniniai sveikatos ịrašai. Išugdžius pacientų pasitikèjimą technologijomis sveikatos priežiūros srityje, diegti ligų diagnozavimo, gydymo, sveikatos stebėsenos ir kitas paslaugas namuose, kurios teikiamos taikant telemedicinos priemones.

Mažinant telemedicinos paslaugų naudojimosi namuose kliūtis, parengti organizuotą visuomenès informavimo strategiją, orientuotą ị vyresnio amžiaus pacientus, be to, sudaryti galimybes praktiškai išbandyti telemedicinos priemones.

Padeka. Straipsnio autoriai dèkoja Vilniaus Šeškinès poliklinikos direktoriui dr. doc. Jonui Kairiui bei direktoriaus pavaduotojai slaugai dr. Renatai Šturienei $u z ̌$ bendradarbiavima ir pagalba atliekant tyrima.

\section{Literatūra}

1. Browns, I. R.; Collins, K.; Walters, S. J., et al. Telemedicine in dermatology: a randomized controlled trial. Health Technology Assessment. 2006, 10 (43): 1-39. 
2. Brownsell, S. Supporting long term conditions and disease management through telecare and telehealth: evidence and challenges [interaktyvus]. London: CSIP, 2008 [žiūrèta 2014-06-25]. <http://www.dhcarenetworks.org.uk/_library/Resources/ Telecare/Support_materials/BriefingTelehealth_SB_Final2.doc>.

3. Chae, Y. M.; Lee, J. H.; Ho, S. H., et al. Patient satisfaction with telemedicine in home health services for the elderly. International Journal of Medical Informatics. 2001, 61(2-3): 167-173.

4. Commission staff working document on the applicability of the existing EU legal framework to telemedicine services accompanying the document Communication from the Commission to the European Parliament, the Council, the European Economic and Social Committee and the Committee of the Regions on eHealth Action Plan 2012-2020 - Innovative healthcare for the $21^{\text {st }}$ century. SWD/ 2012/0414.

5. Communication from the Commission to the European Parliament, the Council, the European Economic and Social Committee and the Committee of the Regions on eHealth Action Plan 2012-2020 - Innovative healthcare for the $21^{\text {st }}$ century. COM/2012/0736.

6. Communication from the Commission to the European Parliament, the Council, the European Economic and Social Committee and the Committee of the Regions of 4 November 2008 on telemedicine for the benefit of patients, healthcare systems and society.COM/2008/0689.

7. Commission White Paper of 23 October 2007 Together for health: A strategic approach for the EU 2008-2013. COM/2007/ 630.

8. Currell, R.; Urquhart, C.; Wainwright, P., et al. Telemedicine versus face to face patient care: effects on professional practice and health care outcomes. Cochrane Database of Systematic Reviews. 2000, 2: CD002098.

9. Dellifraine, J. L.; Dansky, K. H. Home-based Telehealth: a Review and Meta-analysis. Journal of Telemedicine and Telecare. 2008, 14(2): 62-66.

10. Dučinskas, N. Lietuvos e. sveikatos sistemos 2012-2020 metų strategijos vizijos metmenys. Lietuvos Respublikos sveikatos apsaugos ministerija [interaktyvus]. Vilnius, 2012 [žiūrèta 2014-06-29]. <http://www.pylimas.lt/documents/1\%20E.\%20 sveikatos\%20strategijos\%20metmenys \%202012-01-25\%20\%5BCompatibility\%20 Mode\%5D.pdf>.

11. Hyler, S. E.; Gangure, D. P.; Batchelder, S. T. Can telepsychiatry replace in-person psychiatric assessments? A review and meta-analysis of comparison studies. CNS Spectrums. 2005, 10 (5): 403-413.

12. Lietuvos Respublikos sveikatos apsaugos ministro $2007 \mathrm{~m}$. spalio 9 d. issakymas Nr. V-811 „Dèl Lietuvos e. sveikatos 2007-2015 m. plètros strategijos patvirtinimo“. Valstybés žinios. 2007, Nr. 108-4430.

13. Lietuvos Respublikos sveikatos apsaugos ministro $2014 \mathrm{~m}$. sausio $27 \mathrm{~d}$. ịsakymas Nr. V-116 „Dèl telemedicinos paslaugų teikimo tvarkos aprašo patvirtinimo“. Teisès aktų registras [žiūrèta 2014-08-10]. <https://www.etar.lt/portal/legalAct.html?docu mentId=4261443088ac11e397b5c02d3197f382>.

14. Lietuvos sveikatos mokslų universiteto ligoninè viešoji įstaiga Kauno klinikos. Telemedicinos taikymas Vakaru Lietuvos kardiologijai [žiūrèta 2014-10-05]. <http:// www.esparama.lt/paraiska?id=33365\&pgsz $=10>$. 
15. Mair, F.; Whitten, P. Systematic review of studies of patient satisfaction with telemedicine. BMJ. 2000, 320 (7248): 1517-1520.

16. Nimako, K.; Kiong, Lu S.; Ayite, B., et al. A pilot study of a novel home telemonitoring system for oncology patients receiving chemotherapy. Journal of Telemedicine and Telecare. 2013,19 (3): 148-152.

17. Punys, J.; Punys, V.; Eichelberg, M., et al. Pilotinis SAMTA projektas: nebrangios telemedicininès paslaugos periferiniams rajonams. Medicinos informatika: tarptautinès konferencijos pranešimų medžiaga, 2001 m. rugsèjo mèn. 13-14 d. Kaunas: Technologija, 2002, p. 19-32.

18. Rugieniūtè, A. Telemedicinos panaudojimo galimybiu ịvertinimas Kauno medicinos universiteto kliniku padalinių vadovų požiūriu. Magistro darbas. Kaunas: Kauno medicinos universitetas, 2008.

19. Sanders, C.; Rogers, A.; Bowen, R., et al. Exploring barriers to participation and adoption of telehealth and telecare within the whole system demonstrator trial: a qualitative Study. BMC Health Services Research. 2012, 12: 220.

20. Tran, K.; Polisena, J.; Coyle, D., et al. Home telehealth for chronic disease management. International Journal of Technology Assessment in Healthcare. 2008, 25 (3): 339-349.

21. Vaičiūnaitè, L. Ligoniu, sergančių išemine širdies liga, pasitenkinimas ir paklusnumas naudojantis telemedicinos paslaugomis. Magistro darbas. Kaunas: Kauno medicinos universitetas, 2007.

22. Viešoji ìstaiga Vilniaus universiteto ligoninès Santariškių klinikos. Pažangios telemedicinos paslaugos [interaktyvus]. [žiūrèta 2014-10-05]. <http://www.esparama. lt/paraiska?id=31987\&pgsz $=10>$.

23. Whitten, P. S.; Mair, F. S.; Haycox A., et al. A systematic review of cost effectiveness studies of telemedicine interventions. BMJ. 2002, 324: 1434.

24. World Health Organization. Telemedicine: opportunities and developments in member states: report on the second global survey on eHealth. WHO: Geneva, 2010, p. 94 .

\section{Patients' Attitude Towards Home Telemedicine Services}

\section{Ernesta Remeikaité, Gintarè Petronytè \\ Mykolas Romeris University, Lithuania}

Summary. This article focuses on the implementation of telemedicine services in the healthcare sector. The objective of the study is to assess patients' attitudes towards home health care services using telemedicine tools. The cross sectional survey of 279 patients, aged 40-76 years and registered in Vilniaus Seskines polyclinic, was performed in September - November, 2013. Based on the results, patients are not sufficiently informed about the implementation of e-health, including telemedicine services in the health care system. Although patients tend to use home health care services using telemedicine tools, however, indirect communication with a doctor remains unacceptable for patients; therefore, they 
are less likely to use telemedicine services related to diagnostics, treatment and health monitoring. Moreover, patients are concerned about the positive changes in health care access and its quality, health information security, medical mistakes, discomfort with telemedicine tools and lack skills to use them, individual finance investment in telemedicine tools.

Keywords: telemedicine, home-care telemedicine services, barriers to homecare telemedicine use, patients.

Ernesta Remeikaitė, Mykolo Romerio universiteto Politikos ir vadybos fakulteto Politikos mokslų instituto magistrè.

Ernesta Remeikaitè, postgraduate at Mykolas Romeris University, Faculty of Policy and Management, Institute of Political Science.

Gintarẻ Petronytė, Mykolo Romerio universiteto Politikos ir vadybos fakulteto Politikos mokslų instituto lektoré, biomedicinos mokslų daktarè.

Gintarè Petronytė, Doctor of biomedicine, lecturer at the Institute of Political Science, Faculty of Policy and Management, Mykolas Romeris University. 